\title{
Mr. Alfred Hollins on His Australasian Tour
}

Author(s): Alfred Hollins

Source: The Musical Times, Vol. 46, No. 744 (Feb. 1, 1905), pp. 115-116

Published by: Musical Times Publications Ltd.

Stable URL: http://www.jstor.org/stable/903741

Accessed: 23-06-2016 00:12 UTC

Your use of the JSTOR archive indicates your acceptance of the Terms \& Conditions of Use, available at

http://about.jstor.org/terms

JSTOR is a not-for-profit service that helps scholars, researchers, and students discover, use, and build upon a wide range of content in a trusted digital archive. We use information technology and tools to increase productivity and facilitate new forms of scholarship. For more information about JSTOR, please contact support@jstor.org.

Musical Times Publications Ltd. is collaborating with JSTOR to digitize, preserve and extend access to The Musical Times 
of the Exhibition at Milan in 188I to see the collection of Stradivari's tools that was there shown. He made careful researches at Cremona in particular; and also visited Absam, near Innsbrück, on the other side of the Alps, the home of Jacob Stainer.

Mr. Payne formed certain theories on the subject of the tone of violins, and in a lecture which he gave some twenty years ago to the students of the Royal College of Music he expounded his views with considerable ingenuity. Whatever may be the ultimate verdict of those best qualified to judge upon his conclusions on the subject of tone, or on purely historical matters, it must be allowed that there was nothing careless or slipshod about his mode of reaching his results. He accepted no mere gossip or idle tradition such as readily accumulate about famous workers in all careers. At the same time he was a real enthusiast on the subject in hand, holding in the highest esteem the remarkable series of men who succeeded in developing and finally perfecting the most delicate and responsive of all instruments. It is unnecessary to touch on Mr. Payne's scholarly attainments in other directions. We must conclude with a hope that by his premature death the articles which he was preparing for the new edition of Grove's 'Dictionary' are not lost.

\section{MR. ARTHUR CHAPPELL.}

Mr. Samuel Arthur Chappell died, we regret to record, at 45, Brook Street, on December 21, 1904, aged seventy-eight. A member of the family so long connected with the well-known publishing and concert-giving busines in New Bond Street, 'Uncle Arthur,' as he was affectionately called, will be long remembered as director of the Monday Popular Concerts, a position he filled with much distinction for forty years. In THE MUSICAL TIMES of September, I 898 (p. 595), we gave some historical notes on the origin of the far-famed Popular Concerts-financed by Mr. Tom Chappell how they owed their inception to the Cattle Show, though the connection between bullocks and Beethoven, cattle an quartets, does not seem very obvious until the circumstances attending the initiation of the concerts are known.

MR. THEODORE THOMAS.

The death of Mr. THEODORE THOMAS is referred to by our own correspondent at New York, but a few biographical particulars may be given of the distinguished conductor who achieved such well-deserved fame in America. Born at Esens, Hanover, on October II, I835, he was taught the violin by his father and played in public at the age of six. In I 845 the fainily emigrated to New York, where Theodore played in an orchestra, subsequently (in I85I) going on a concert-tour - as a soloist in the company of Jenny Lind, Grisi, Sontag, Mario, and others. He played in various opera orchestras, sometimes conducting, until I86I, but three years later he organized an orchestra for 'Symphony Soirées' at Irving Hall, New York, this venture being the beginning of his eventful career as an orchestra conducto in New York, Chicago, and elsewhere in the United States It has been truly said that Theodore Thomas 'has done more than any other man to raise the standard of music in America.' This honourable record of something attempted, something done, is borne out by Mr. Krehbiel's appreciation on page II 8 of our present issue, to which the reader is referred.

Other recent deaths are those of Frank Celli, at Charing Cross Hospital, formerly well known as an operatic baritone; Madame BELle Cole, a popular American contralto, who died in London on January 6, aged sixty and FREDERICK ENOCH, writer of lyrics and author of many popular songs, whose death took place at Ringmer, Sussex, at the age of seventy-seven.

The next conference of the Girls' School Music Union will be held on Saturday, February 25, at the Kensington High School, St. Alban's Road, at 3 p.m., Lady Mary Lygon in the chair. Mrs. Woodhouse, of Clapham High School, and Miss Elsa Froebel will jointly contribute a paper on 'The desirability of special training in the teaching of music.'

\section{MR. ALFRED HOLLINS ON HIS AUSTRALASIAN TOUR.}

\section{EDINBURGH, January I2, I905.}

A gentleman whom I met in New Zealand came over to Scotland a few years ago to spend a holiday at his uncle's estate. One day, as they were walking through the grounds, they came across the gamekeeper. 'This is my nephew from New Zealand,' quoth the uncle. The gamekeeper stared hard for a few seconds, and then said in characteristic Scotch fashion: 'Why! he's no' black.' I am afraid not a few of us home-birds have equally strange notions of our Colonial cousins, in fact, they jokingly tell us that we need to go out there in order to be brought ' up to date'! They are a warm-hearted, enthusiastic kinsfolk, eager to receive and welcome everything new.

We left Tilbury Docks on May 20 last on board the good ship Ortona, of the Orient-Pacific line. A more comfortable and safe vessel, manned by kinder or more attentive officers, from Captain Fletcher downwards, one could not desire. I was most anxious to learn all I possibly could about the ship and its working, and if Mr. Turnbull, the genial Chief Engineer, is bothered every voyage with so inquisitive a passenger, I wonder he is alive to tell the tale. I shall always be grateful to him for his kindness and patience in explaining every detail of the engines to me; and what a revelation it was to go down into the engine-room and be able to see with my own 'ten eyes' all that vast machinery. The verse often came into my mind, 'They that go down to the sea in ships,' \&c. Indeed, one thing that has impressed me perhaps more than any other is the enormous amount of work and care involved in the manage. ment of a steamship on a long voyage. But I am forgetting that I have been asked to write an account of our trip for The Musical Times.

The first music we heard was the band on board one of our ironclads, playing at the hoisting of the Union Jack, and although we had then travelled more than a thousand miles, its cheery sound made us feel very near home. It was with great pleasure we saw by the passenger list that Paderewski was to be one of our fellow voyagers. I had never met this great artist, and the pleasure was increased when I was introduced to him, and found after a very short time that he is not only a great musician, but a most courteous gentleman and synipathetic friend. He endeared himself to every one on board, and had a kindly smile and word for all. The same may be said of his charming wife : no wonder they win love and admiration wherever they go. I had many pleasant chats with Mr. Adlington, Paderewski's clever manager and friend, who often entertained me with stories of his experiences as a concert agent. Perhaps the greatest delight of the whole voyage was to sit and listen to Paderewski practising. I wish all students of music could have had this grand opportunity. One thing is certain, he is no trickster, but has obtained his great mastery of the pianoforte by enormous hard work. He meant to give Australia his very best, and to that end would practise even on board ship never less than three hours a day. The patience and care he bestows on passages even of the slightest difficulty are a lesson to all. I shall not speak of the various places we touched at, but I must just mention our stay at Naples. Here we were serenaded by parties of singers who accompanied themselves on guitars and mandolines. Their voices were not pretty, but there was a certain charm in lying in one's berth and hearing Italian canzonettas from a distance across the peaceful bay.

The first Australian city we visited was Adelaide, where we were met by Mr. A. W. Hendry, the enterprising superintendent of the Royal Institution for the Blind. $\mathrm{He}$ is a very clever and energetic man, and is doing much to advance the cause of the blind in Adelaide. I also made the acquaintance of Mr. Ernest Wood, organist of Melbourne Cathedral, who very kindly gave me the opportunity of trying his fine Lewis organ. This was interesting, as I had given a recital on the instrument in the factory before it was shipped to Australia. On my return to Melbourne I was present at a service in the Cathedral. I believe the Cathedral authorities spend more on their music than any other church in the Colonies, and the choir is considered the best church choir in Australasia; at any rate, I thought it extremely good and enjoyed the service immensely, especially the 
chanting, which reminded me very much of that at the Temple Church in dear old Father Hopkins's days. Mr. Wood's accompaniments were tasteful and devotional.

We reached Sydney early on Saturday morning, July 2. To see that glorious harbour with its innumerable points and bays opening out before one as the ship slowly steams between the huge Heads, must indeed be one of the sights of the world. There are four things of which Sydney people are justly proud : the Harbour, the Post Office, the Town Hall, and their colossal organ, built by Hill. We were warmly received by Mr. Arthur Mason, the City Organist, Mr. Nesbitt, the Town Clerk, and others. Indeed, Mr. Mason was most cordial and kind throughout our stay. I said that the Sydney people are justly proud of the organ; it is a noble instrument! The hall, when full, is acoustically perfect, and the organ is splendidly placed. It had been thoroughly cleaned, preparatory to my visit, by Mr. Charles Richardson, whose careful attention to the organ during my recitals added greatly to my comfort. The choir and solo organs are now enclosed in swell boxes, the crescendo pedals balanced, instead of being levers-a great advantage, in my opinion, and a glockenspiel, consisting of two octaves of steel bars, 2 -feet pitch, has been added to the solo organ. It would be well if the City Council could see their way to having the entire key action modernized, as at present it is not equal to concert work. My final recital took place on Saturday, October 8, but I gave an extra one the following day, Sunday, as a mark of appreciation to my audiences. There were over five thousand people present, the corridors and outer hall being also crowded, and though many of the audience had to stand, the quietness which prevailed throughout the recital was marvellous, indeed, it was a marked feature at every performance.

Since my return, the one question I have been asked more than any other is 'Are the Australians musical?' I would undoubtedly answer 'Yes.' I do not think it possible to find more attentive or appreciative audiences than those I played to in Sydney, and it surprised and delighted me to see with what warmth and enthusiasm the Bach numbers were received. I met many enthusiastic music teachers, and the musical examinations, conducted yearly by the representatives of the various examining bodies of this country, are doing much to foster a love for the best music in our Colonies. Sydney possesses a really excellent amateur orchestra, the result of the indefatigable labour of its founder and admirable conductor, Signor Hazon. I had hoped to have the pleasure of playing a concerto at one of the Society's concerts, but this was impossible. A quartet of strings, formed by four members of the Sydney College of Music, with Mr. Alpress as leader, were kind enough to entertain me one evening, and played Dvorák's beautiful Trio for two Violins and Viola, and Beethoven's Quartet in $\mathrm{C}$ ninor. Mr. Alpress is a magnificent violinist, and consider this combination one of the finest I have ever heard. By-the-way, the College did me the honour to make me one of its patrons, at the same time presenting me with a neat little gold badge.

I cannot speak too warmly of the cordiality of the Sydney musicians: the organists very kindly entertained me at dinner, and a delightful function it was. The principal Episcopal churches are the Cathedral and St. James's. Mr. Joseph Massey, a fine church player, is organist of the former. He has a large Hill instrument, a splendid example of a church organ, placed in a gallery over one of the transepts. Mr. Mason is organist of St. James's, where the ritual is much higher. His organ, I believe, was originally a Gray and Davison, but it has been enlarged by a local builder. The Sydney Philharmonic Society performed the 'Creation' and 'Samson' during our stay, but I was unable to be present on either occasion. Colonials thoroughly appreciate talent in their countrymen, and if a student shows decided musical gifts, his fellow townsmen immediately get up a complimentary concert to raise funds in order that he may be sent home to complete his studies. We visited the Blind Institution, where we had a warm welcome. There are only fifteen or sixteen pupils at present, and these, unfortunately, are boarded with the deaf and dumb, of which there are a considerable number. Mr. Arthur Massey teaches the blind children music, and is doing good work.

On October I 5 we sailed for Invercargill, the southernmost town in New Zealand, calling at Wellington, Christchurch, and
Dunedin on the way. The Corporation of Wellington have just built a fine Town Hall, for which a large organ is being erected by Messrs. Norman and Beard. At Dunedin I was much interested in the peculiar chimes of the Town Hall clock. There are five bells, the notes being

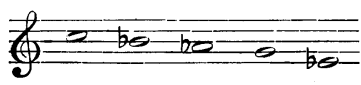

The only chime I remember is the three-quarters :

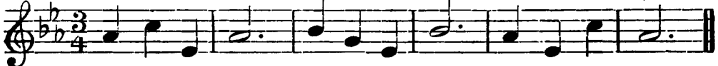

I tried to find out their history, but no one could tell me, or had even seemed to notice they were not the well-known Westminster chimes, which are so common on all public clocks throughout Australasia. We spent a most delightful week at Invercargill, where I gave recitals on a new and charming little three-manual organ by Messrs. Norman and Beard, in St. John's Church. Mr. Charles Gray, the organist, is doing splendid work there. Besides his church choir, which is extremely good, he has an excellent Choral Society and a small orchestra, and, with his two clever lady assistants, does nearly all the teaching in the town. Invercargill is a Scotch settlement, and all its streets are named after the rivers in Scotland. There are two Presbyterian churches; the first of these has a remarkably good little choir, most carefully trained by an enthusiastic amateur, Mr. W. Quinn. Our stay here came all too quickly to an end, and we left by way of Hobart on October 31 for Melbourne, arriving there the following Sunday.

Before sailing for honie on November 8 we spent two days with Professor Baldwin Spencer and his family at their charming house in the University grounds. Professor Spencer has recently been made a C.M.G. on account of his splendid researches among the aborigines of Australia. He was most kind in showing and explaining to me his wonderful collection of native curiosities, and altogether our visit to him was one of the chief interests of our trip. I renewed my acquaintance with Professor Franklin Peterson, whose Conservatorium in connection with the University seems to be flourishing. Mr. Guilfoyle, the director, very kindly showed us over the Melbourne Botanical Gardens, which are among the very finest in the world. On the morning of Tuesday, November 8, we embarked on the Ortona once more, and right glad we were to be able to return home in the good ship which had brought us out so safely. The days of the voyage passed very pleasantly for me, through the kindness of one of our fellow passengers, Professor Kirk, of Wellington, who gave me some lessons in chess. After entering the Red Sea, there was a gradual diminuendo in the sunshine and, consequently, the heat, till we landed at Plymouth on December I 5, in real English drizzle and fog : but in spite of that, we felt, as all must feel who have any love for it, that 'There's no place like home.' Alfred Hollins.

THE INCORPORATED SOCIETY OF MUSICIANS. THE ANNUAL CONFERENCE.

From Monday, January 2, to the following Friday inclusive the members foregathered at Manchester, their headquarters being the Midland Hotel. The proceedings began on the evening of the opening day with a reception by the Manchester section. On the following morning the Lord Mayor of Manchester (Alderman T. Thornhill Shann) presided at the inaugural meeting held in the Town Hall. After his Lordship had welcomed the members, Mr. Edward Chadfield, the Secretary, read the annual report, which told of an increase of membership during the year and continued activity in all branches of the Society's work. The Orphanage Report was also of a satisfactory nature. Mr. T. Henderson then read a paper on 'Some Blots on English Music,' the headings of his discourse being 'The Theatre Band,' 'The Brass Band,' 'The Choral and Orchestral Society,' and 'Time.' In the afternoon Sir Frederick Bridge discoursed on 'A Weak Point in our Musical Education.' Sir Frederick said : ' The weak point to which
he wished to call attention was the deplorable and general 